Available online at $\mathrm{http} / / / \mathrm{bajas} . \mathrm{edu} . \mathrm{iq}$
$\mathrm{https://doi.org/10.37077/25200860.2019.201}$
College of Agriculture, University of Basrah
Basrah Journal of

Agricultural

Sciences

ISSN 1814 - 5868 Basrah J. Agric. Sci., 32(2): 106-114, $2019 \quad$ E-ISSN: 2520-0860

\title{
Morphology of Digestive Tract and Feeding of the Invasive Chinese Mitten Crab, Eriocheir sinensis (H. Milne Edwards, 1853) (Decapoda: Brachyura: Varunidae), Southern Iraq
}

\author{
Intisar M.A. Jabbar ${ }^{1}$, Entisar N. Sultan ${ }^{2 *} \&$ Salah M. Najim² \\ ${ }^{1}$ Department of Biology Marine, Marine Science Centre, University of Basrah, Iraq \\ ${ }^{2}$ Department of Fisheries and Marine Resources, College of Agriculture, University of \\ Basrah, Iraq
}

*Corresponding author E. mail:entsarnaeem @gmail.com

Received 17 June 2019; Accepted 14 October 2019; Available online 31 December 2019

\begin{abstract}
The digestive tract in Eriocheir sinensis consists of the alimentary canal which includes a foregut consisting of the mouth, esophagus, and stomach. The mouth is surrounded by several pairs of appendages which are specialized for chemoreception and prey capture while esophagus is short and straight moves food from mouth to the stomach, which look like an oval sac divided in to two parts called the cardiac chamber and the pyloric chamber. The composition of digestive tract were investigated and the diet analysis was assessed using two methods: points and frequency of occurrence. The main food items included eight types, the highest percentage of $43.6 \%$ shrimp, $42.8 \%$ detritus and $14.5 \%$ sand, while the lowest were $(0.39 \%, 0.69 \%$ and $0.97 \%$ for eggs, plants and filament algae respectively. Feeding intensity and activity values arranged between $12-15.9$ and 76 - 86\%, respectively, while the Vacuity index were $14-31.6 \%$, and Feeding index values were $59.9-79.7 \%$.
\end{abstract}

Keywords: Eriocheir sinensis, digestive tract, food composition, invasive crab.

\section{Introduction}

The Chinese mitten crab Eriocheir sinensis (Milne-Edwards, 1853), commonly called the river crab, Shanghai crab and Chinese freshwater edible crab (Gollasch, 2011). This is the largest crustacean species inhabiting Polish waters. The first record of E. sinensis H. Milne Edwards, 1853 (Crustacea: Brachyura: Varunidae) from the Basrah Area of Southern Iraq (Clark et $a l, 2006)$. It is a catadromous species that spends most of its life in freshwaters and only migrates to the sea for mating, spawning and larval growth. The migration is happnd during the autumnal months and the adults will die after mating. The migration of $E$. sinensis occur when the larvae migrate from marine to the river, and reflected to be an domestic species in Asia, with indigenous deal along the China and Korean (Gu \& Zhao, 2001).

Lowe et al. (2004) showed that the mitten crab E. sinensis is one of two of the worse crabs species on the world. It has been recorded in list of 100 most aliens 
aquatic invertebrates. It has been become as an invasive species in Europe and northern America, maybe received to the coasts by ballast water of ships (Rudnick et al., 2003; Herborg et al., 2003; 2007;). This migrating species occurs in rivers, estuaries and marine habitats of cold temperate to tropical climate areas from lower shorelines to about $10 \mathrm{~m}$ in depth. These species are tolerant to highly polluted water.

In China E. sinensis have a high economic value and it's a most delicious sea food for Chinese consumers. (Chen \& Zhang, 2006), its diet composition from algae, vascular plants, detritus, inorganic matter, animal remains, eggs and fish, it's also feed on fishes caught in traps and nets. Nets will be damaged (Cohen \& Carlton, 1998; Rudnick et al., 2003), Copepods, eggs of Chronomids and macroinvertebrates (Czerniejewski \& Wawrzyniak, 2006). Ding et al. (2017) investigated the changes in composition and structure of the crab gut microbiome during various WSSV infection stages of $6 \mathrm{~h}$ post-infection (hpi) and $48 \mathrm{hpi}$, using a $16 \mathrm{~S}$ rRNA approach on the MiSeq Illumina sequencing platform.

The main objective of this research was to describe the digestive system and

The percentage of feeding activity $=($ Diet individuals/Investigated individuals $) \times 100$

Vacuity index calculated according to the following expression (Maia, 2006):

Vacuity index $=($ Number of Vacuity/ Investigated individuals $) \times 100$

The Intensity feeding was measured according to Dipper et al. (1977):

Intensity of feeding $=($ Total number of foregut fullness/ Diet individuals $)$.

Feeding index was determined according to Mohanty (2002), by using the following equation:

Feeding index $=($ Total degrees of foregut fullness $\times 100) /($ Diet individuals $\times$ foregut fullness $)$ 


\section{Results}

The digestive tract of crab is classically divided into five parts: mouth, oesophagus, stomach, hepatopancreas, midgut and hindgut. The position of the mouth is on the abdominal side of the vertical area surrounded by several pairs of appendages and jaws which are specialized for chemoreception and prey capture (Pic. 1).
The oesophagus is a short vertical structure its generally moves food from mouth to the stomach. While, The stomach is midday in the vertical chest and having elliptic form. The hepatopancreatic are tergally and framing the midgut completely. The midgut which is the longest part in digestive tract of the crab, and the hindgut passage to the anus (Pic. 2).

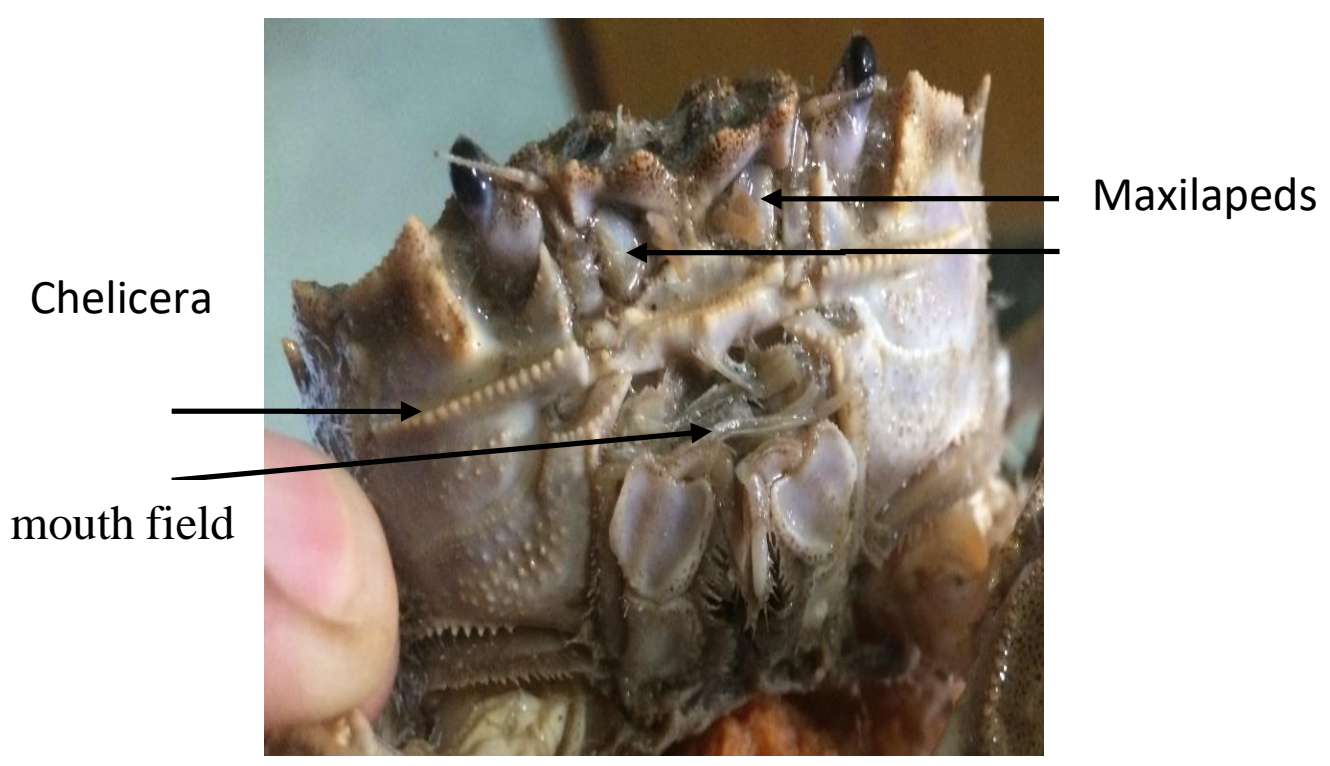

Pic. (1): Jaws and mouth of $E$. sinensis. 


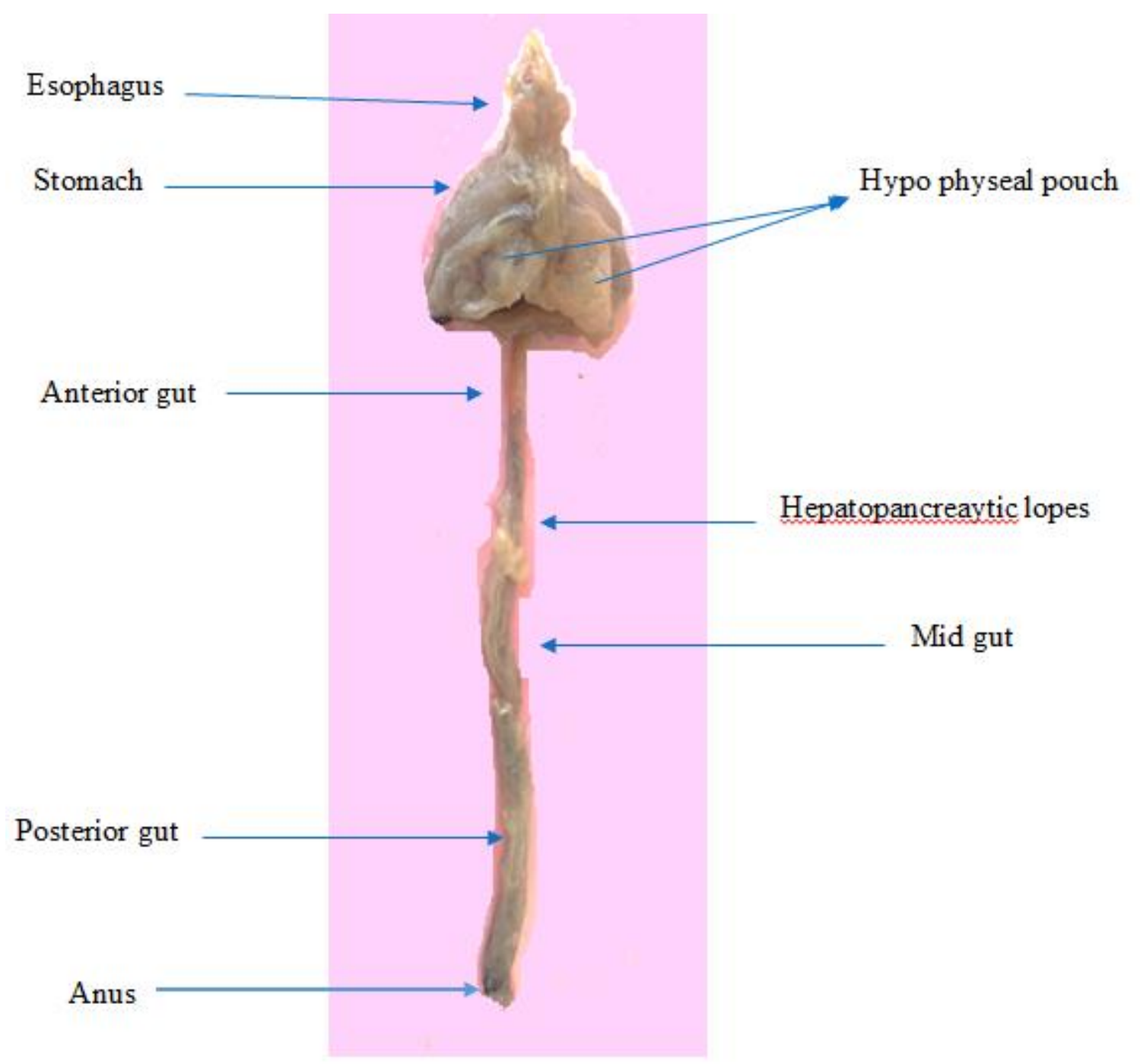

Pic. (2): The digestive tract of $E$. sinensis comprises the five parts: Mouth, oesophagus, stomach, hepatopancreas, midgut, and hindgut was taken by digital camera.

Table (1): The percentage of the composition of food items calculated by points method of $E$. sinensis sampled from 200 crab's foregut content from southern Iraq.

\begin{tabular}{lcccccccc}
\hline dietary categories & Autumn & \multicolumn{3}{c}{ Winter } & \multicolumn{3}{c}{ Spring } & \multicolumn{3}{c}{ Summer } \\
\hline & points & $\%$ & points & $\%$ & points & $\%$ & Points & $\%$ \\
\hline Shrimp & 180 & 31.3 & 145 & 28.57 & 299 & 43.6 & 190 & 37.25 \\
\hline Eggs & 14.5 & 2.52 & 2 & 0.39 & 8 & 1.16 & 7 & 1.37 \\
\hline Mollusca & 10.5 & 1.82 & 26 & 5.04 & 26 & 3.82 & 9.5 & 1.26 \\
\hline Plants & 4 & 0.69 & 20 & 3.88 & 12.5 & 1.82 & 10.5 & 2.06 \\
\hline Diatoms & 33.5 & 5.82 & 12 & 2.23 & 24.5 & 3.57 & 12.5 & 2.45 \\
\hline Filament algae & 11.5 & 2 & 5 & 0.97 & 16.5 & 2.4 & 12 & 2.3 \\
\hline Detritus & 246 & 42.8 & 138 & 26.8 & 199 & 29.05 & 197.5 & 38.7 \\
\hline Sand & 75 & 13 & 67 & 13 & 99.5 & 14.5 & 71 & 13.9 \\
\hline
\end{tabular}


The number of specimens of E. sinensis collected for study were 200 individuals. The results showed there were eight types of diets through four seasons.

Overall, The percentage of composition of food items calculated by points method and frequency method were presented in (Table 1, fig. 1), The identifiable food items was included the shrimp remains occurred at a highest and more frequency of $43.6 \%$, then detritus at $42.8 \%$, Sand at $14.5 \%$, and Mollusca remains at $5.04 \%$, diatoms at $5.82 \%$. while the lowest percentage of food items and less frequency were eggs at $0.39 \%$, plant at $0.69 \%$ and filament algae $0.97 \%$ (table 1 , fig. 1).

Feeding activity, intensity feeding and vacuity index were recorded the highest percentages were $86 \%, 15.9 \%, 31.6 \%$, while the lowest were $76 \%, 12 \%, 14 \%$ were showed in fig. (2), and the results showed that the highest values of feeding index between 79.7-59.9 (deg./ind.).

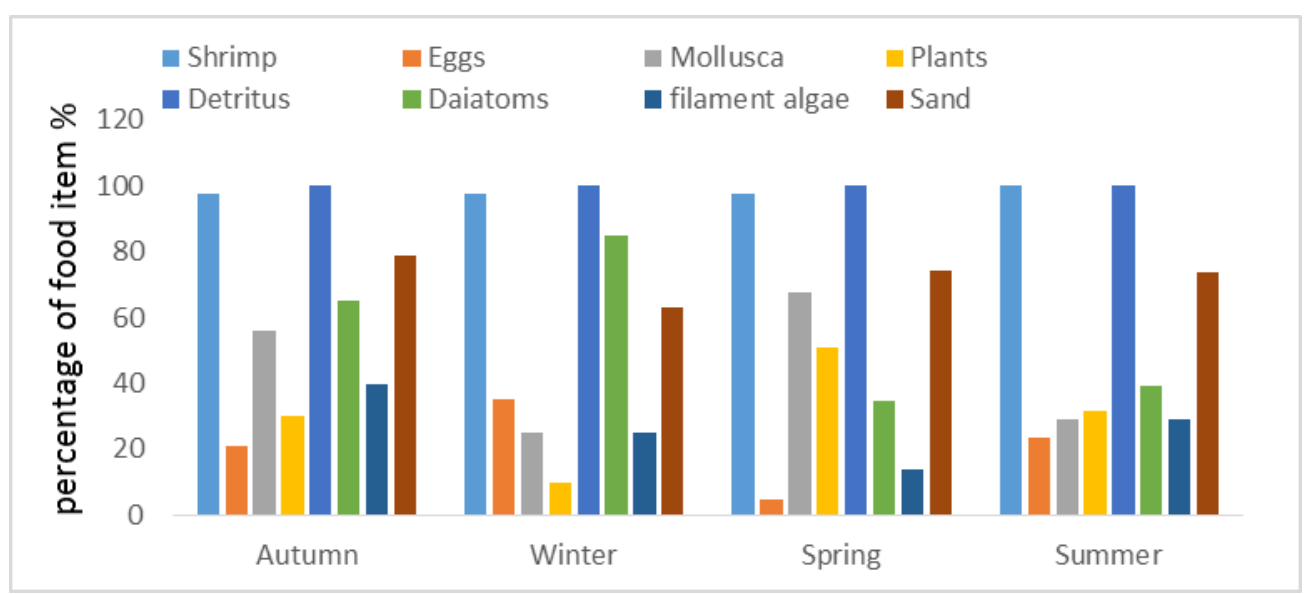

Fig. (1): The percentage of the composition of food items of $E$. sinensis calculated by frequency method.

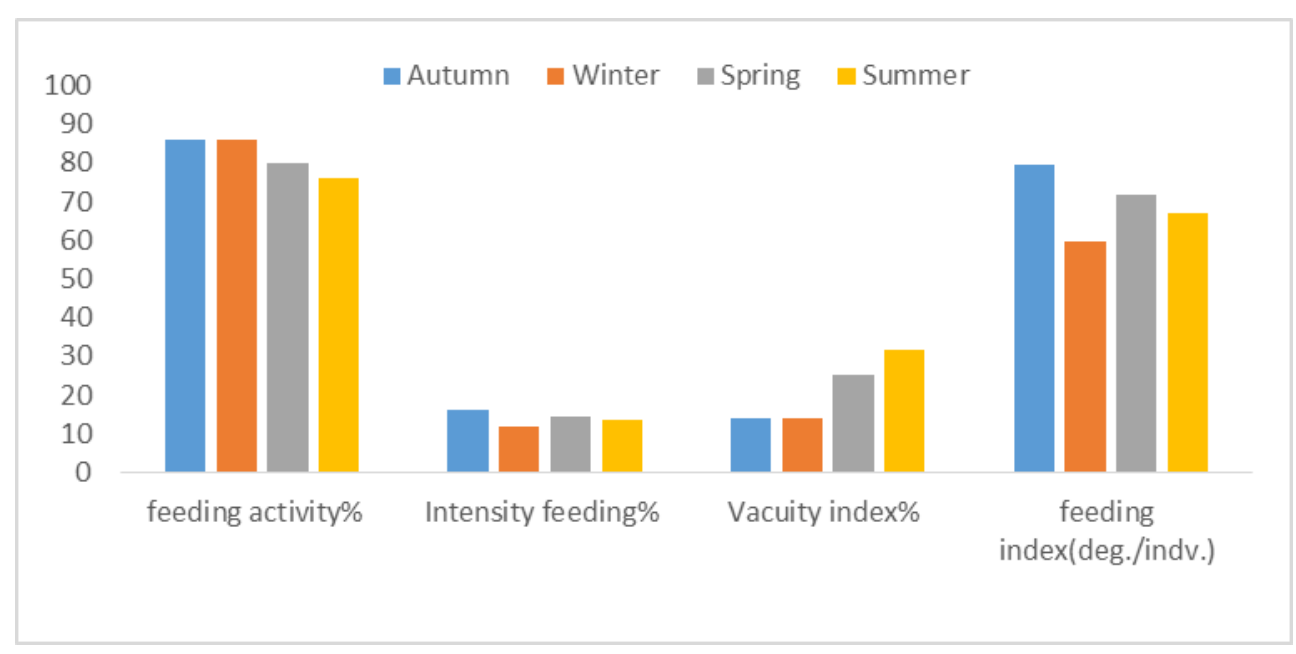

Fig. (2): The percentage of feeding activity, vacuity, intensity feeding, and feeding index of $E$. sinensis. 


\section{Discussion}

The crustacean digestive system are similar to other species, in its complex structure. The oesophagus is a simple muscular tube which allow the food pass to the stomach. The wall of the stomach are changing. The distension degree depends on the size and amount of food confront with that found in big decapod (De Jong \& Casanova, 1997). The stomach is a simple pouch without calcified structures in the interior, So, the cardiac chamber of the decapoda is cardiac or like a ball has calcified elements in the anterior wall, also crustaceans giving expression a set of highly active digestive enzymes that analysis the food (Boschi, 1981; Veroonica \& Gimenez, 2013).

The muscular gut were development that has for completed mix and digestive food by enzymes that hepatopancreas which excreted than become absorbable soft mass (Saborowski et al., 2012). Without doubt that, the activity of digestive are impacted via numerous factors, such as food, molting process, and growth. According to Rudnick \& Resh (2005), this species was showed the ingredients of the diet, that the most frequent food of the crabs found in the Odra estuary $40 \%$ detritus, with $28.1 \%$ plants and $25.4 \%$ animals of the crabs respectively being less frequent, copepods and chironomid larvae dominated the animal fraction of the food.

In most decapods, food is rushing to the midgut from stomach, and by polystictus the digestive is completely (Pillai, 1960).

The hindgut of this crab similar in characteristics, composition and internal anatomy with other crustacean species, but differ in size, they are bigger and its walls stretch according the discussing diet, the walls is viscous, having cells forming a cycle around the anus. (Johnston \& Alexander, 1999). As for the molecules are uncluttered it has been driven from hindgut and going out the body (Lin, 2000; Daz et al., 2006).

Crabs are omnivorous, opportunism, and predacious species, its consume different foods and some them classified as herbivorous, for there were diatoms, filament algae and aquatic plants In their gut (Tina \& Darumas, 2014).

The results showed that the highest percentage of food in gut were shrimp 43.5 $\%$, then detritus $40.15 \%$, while the lowest was eggs. These results agree with a lot of studies in the world about Brachyurans, that because of their high digestive efficiency (DeLestany, 2000). So, in some Portunodae species, Ikhwanudein et al. (2009) found about $25 \%$ decapod and crustaceans in their gut while, Josileen (2011) has been found about $73.43 \%$ from remains, which belong to shrimps' legs, diatoms, Mollusca and fish in Portunus pelagicus gut (Al-Mamunt et al., 2008 ) found $44.4 \%$ crustacean, $26 \%$ molluscan, $15 \%$ fish, $10 \%$ and plants in the gut of the mud crab Scylla serrata.

During winter and autumn, the annual catch estimated and intensity feeding increased and being higher than the other seasons maybe because of the transparent water that increases crabs ability to see the pray or because of the slowly moving of the pray, these results agree with Mohanty (1996) and AlMamunt et al. (2008).

The Chinese mitten crabs in coastal water feed mainly on remains, macroinvertebrates, and plants, some studies showed a similar 
results such as Rudnick \& Resh (2005), who studied the Chinese mitten crab, E. sinensis in San Francisco Bay, showed that the large ingredients of the crabs food were algae and remains, the favourite food for crabs is macroinvertebrates, So when crabs given four types of food (algae, detritus, macro invertebrates, and shrimps), they choice the macroinvertebrates (Czerniejewski et al., 2010).

\section{Conclusion}

The basal food of the Chinese mitten crab, $E$. sinensis, in the coastal water body southern Iraq was regarded to consist in remains and animals this indicates that the Chinese mitten crab also fed on macroinvertebrates such as shrimps and Mollusca, eggs and diatoms. It is noticeable that the intensity and activity of this crab increase in winter and season.

\section{Acknowledgement}

Thanks for Department of Fisheries and Marine Resources, College of Agriculture, University of Basrah, for their support during the laboratory work.

\section{References :}

Almamunt, A.; Begum, M.; Mia, M.Y. \& Alam, M.J. (2008). Food and feeding habits of the mud crab, Scylla serrata (Forsskal) in Bangladesh. J. Bangladesh Soc. Agric. Sci. Technol., 5(3-4): 141-144.

Boschi, E.E. (1981). Decapoda Natantia. In: Fauna de agua dulce de la República Argentina. Vol. 26. FECIC, Buenos Aires: $61 \mathrm{pp}$.

Chen, D. \& Zhang, M. (2006). Analysis of volatile compounds in Chinese mitten crab, (Eriocheir sinensis). J. Food Drug Anal., 14(3): 297-303.
Cohen, A.N. \& Carlton, J.T. (1998). Accelerating invasion rate in a highly invaded estuary. Science, 279: 555-558.

Czerniejewski, P. \& Wawrzyniak, W. (2006). Seasonal changes in the population structure of the Chinese mitten crab, Eriocheir sinensis (H. Milne Edwards) in the Odra/Oder estuary. Crustaceana, 79: 1167-1179.

Czernijewski, P.; Rybckyk, A. \& Wawrzyniak, W. (2010). Diet of the Chinese mitten crab, Eriocheir sinensis $\mathrm{H}$. Milne Edwards, 1853, and potential effects of the crab on aquatic community in the River Odra/Oder estuary (N.-W. Poland). Cructaceana 83(2): 195-205.

Daz, A.C.; Sousa, L.G. \& Petriella, A.M. (2006). Morphplogia, histologia del aparato digestive en los diferentes estadios de vida de los camarones peneidos. 7-23. In Rosas, C.; Cariollo, O.; Wilson, R. \& Andreatta, E. (Eds.). Estado actualy perspectivas de la nutrieion de los camarones peneidos cultivados en Iberoameica. Mexico D. F.: Publidisa Mexicana: 322pp.

De Jong, L. \& Casanova, B. (1997). Comparative morphology of the foregut of three Eucopia species (Crustacea, Mysidacea, Lophogastrida). J. Nat. Hist., 31: 389-402.

De Lestang, S.; Platell, M.E. \& Potter, I.C. (2000). Dietary composition of the blue swimmer crab, Portunus pelagicus L. Does it vary with body size and shell state and between estuaries? J. exp. Mar. Biol. Ecol., 246: 241-257.

Ding, Z.F.; Cao, M.J.; Zhu, X.S.; Xu G.H. \& Wang, R.L. (2017). Changes in the gut 
microbiome of the Chinese mitten crab, (Eriocheir sinensis) in response to white spot syndrome virus (WSSV) infection. J. Fish. Dis., 40(11): 561-1571.

Dipper, E.; Bredges, C. \& Menz, A. (1977). Age, growth and feeding in the ballon wrasse Leburs bergylta. J. Fish Biol., 11: 105-120.

Gollasch, S. (2011). NOBANIS- Invasive alien species fact sheet-Eriocheir sinensis. Online Database of the European Network on Invasive Alien Species NOBANIS. www.nobanis.org, Date of access $\mathrm{x} / \mathrm{x} / 201 \mathrm{x}$.

Gordan, J.D. (1977). The fish population in store water of west coast Scotland. The food and feeding of whiting Merlanguis merlanguis. J. Fish Biol., 11(6): 512-529.

Gu, X.H. \& Zhao, F.S. (2001). Resources and culturing situation of Chinese mitten crab, (Eriocheir sinensis) and species character conversation. Chin. J. Lake Sci., 13: 267271 (In Chinese with English abstract).

Herborg, L.M.; Rushton, S.P.; Clare, A.S. \& Bentley, M.G. (2003). Spread of Chinese mitten crab, (Eriocheir sinensis H. Milne Edwards) in continental Europe: Analysis of a historical data Set. Hydrobiologia, 503(1): 21-28.

Hynes, H.B.N. (1950). The food of freshwater stickle backs (Gasterosteus aculeatus) and (Pygosteus ounjitius) with a review of methods used in studies of fishes. J. Anim. Ecol., 19(1): 36-58.

Herborg, L.-M.; Weetman, D.; van Oosterhout, C. \& Hänfling, B. (2007). Genetic population structure and contemporary dispersal patterns of a recent European invader, the Chinese mitten crab,
Eriocheir sinensis. Mol. Ecol., 16: 231242.

Ikhwanuddin, M.; Shabdin, M.L. \& AbolMunafi, A.B. (2009). Catch Information of blue swimming crab portunus pelagicus from Sarawa coastal water of south china sea. J. Sustain. Sci. Manage., 4(1): 93-103.

Johnston, D.J. \& Alexander, C.G. (1999). Function morphology of the mouth parts and alimentary tract of the slipper lobster, Thenus orientalis (Decapoda: Scyllaridae). Mar. Fresh water Res., 50: 213-223.

Josileen, J. (2011). Food and feeding of the blue swimming crab, Portunus pelagicus (Linnaeus, 1785) (Decapoda, Branchyura) along the coast of Mandapan, Tamil nadu, India. Crustaceana, 84(10): 1169-1180.

Lin, F.Y. (2000). Scanning electron microscopic observations on the gland filter of the pyloric stomach of Penaeus monadon and Metapenaeus ensis (Decapoda, Penaeidae). Crustaceana, 73(2): 163-174.

Lowe, S.; Browne M.; Boudjelas S. \& De Poorter, M. (2004) 100 of the world's worst invasive alien species. A selection from the global invasive species database. Published by the Invasive Species Specialist Group (ISSG) a specialist group of the Species Survival Commission (SSC) of the World Conservation Union (IUCN): $12 \mathrm{pp}$.

Maia, A.; Queiroz, J.; Correia, P. \& Correia, H. (2006). Food habits of the short fin mako, Isurus oxyrinchus, of the southwest coast of Portugal. Environ. Biol. Fish., 77: 157-167. 
Mohanty, R.K. (1996). Effect of turbidity and its management in aquaculture. Fish. World, 3(9): 24-25.

Mohanty, R.K. (2002). Performance evaluation of fry to advanced fingerling stage rearing of Indian Major crabs in run off collection tank. J. Inland Fish. Soc. India, 34(2): 1-6.

Pillai, R.S. (1960). Studies on the shrimp caridina laevis (Heller). 1. The digestive system. J. Mar. Biol. Assoc. India, 2: 5774.

Pinoni, S.A.; Mendez, E. \& Lopez Mananes, A.A. (2015). Digestive flexibility in a euryhaline crab from a SW Atlantic coastal lagoon: alkaline phosphatase activity sensitive to salinity in the hepatopancreas. J. Mar. Biol. Assoc. U. K., 95: 1133-1140.

Rudnick, D.A., Hieb, K., Grimmer, K.F., and Resh, V.H. (2003). Patterns and processes of biological invasion: The Chinese mitten crab in San Francisco Bay. Basic Appl. Ecol. 4: 249-262.

Rudnick, D. \& Resh, V. (2005). Stable isotopes, mesocosms and gut content analysis demonstrate trophic differences in two invasive decapod crustacea. Freshwater Biol., 50: 1323-1336.

Saborowski, R.; Schatta, J. \& Gimenez, L. (2012). Catalytic propertiones and polymorphism of serine endopeptidases from the midgut gland of the brown shrimp Carangon crangon (Decapoda, Cardea). Mar. Biol. 159:11071118 .

Tina, F.W. \& Darumas, U. (2014). Feed acceptability survival and growth performance of blue swimming crab, Portunus pelagicus fed with different cheaper diets. Multi. Disciplinary Edu. Global Quest (Quarterly), 3: 31-40.

Veroonica, A. \& Gimenez, F. (2013). Digestive physiology of three species of Decapod Crustaceans of Argentina. J. Shellfish Res., 32(3): 767-777. 